\title{
Developmental haemostasis in moderate and late preterm infants
}

\author{
Mario Motta*, Fabio Giovanni Russo \\ From XX National Congress of the Italian Society of Neonatology \\ Rome, Italy. 9-11 October 2014
}

\section{Introduction}

The term "developmental haemostasis" was first coined by Maureen Andrews to describe the age-related physiological changes of the coagulation system during childhood.[1] Given the age-dependent specificity of haemostasis, the evaluation and the interpretation of coagulation assays in newborns may present diagnostic difficulties and appropriate reference ranges for the diagnosis and management of coagulopathies in moderate and late preterm infants are needed.

\section{Age-related changes in the coagulation plasma proteins}

The haemostatic system is a dynamic evolving process that is age-dependent. At birth, plasma concentrations of vitamin K-dependent and contact factors (F) are decreased if compared with adult levels.[2] During the first 6 months of life, they gradually increase to values approaching adult levels.[2] These changes in protein levels lead to corresponding changes in global tests of coagulation such as the Prothrombine Time and the Activated Partial Thromboplastin Time. Plasma concentrations of fibrinogen, FV, FVIII, FXIII and von Willebrand are not decreased at birth.[2] In addition, plasma concentrations of antithrombin, protein $\mathrm{C}$ and protein $\mathrm{S}$ are low at birth, and they reach adult levels at about 612 months of life.[2] In the fibrinolytic system, plasma concentrations of plasminogen are decreased at birth, whereas tissue plasminogen activator and plasminogen activator inhibitor are increased.[2] These postnatal changes in the coagulation system, observed both in term and preterm neonates, are functionally balanced, suggesting a normal haemostasis during early infancy in healthy conditions.

Table 1 Reference values for coagulation tests in healthy moderate and late preterm neonates (30 to 36 weeks of gestation) during the first 6 months of life.

\begin{tabular}{|c|c|c|c|c|c|c|}
\hline Postnatal Age & PT (s) & APTT (s) & Fibrinogen $(\mathrm{g} / \mathrm{L})$ & AT-III $(\mathrm{U} / \mathrm{mL})$ & Protein C $(\mathrm{U} / \mathrm{mL})$ & Protein $\mathrm{S}(\mathrm{U} / \mathrm{mL})$ \\
\hline Day 1 & $\begin{array}{c}13.0 \\
(10.6-16.2)\end{array}$ & $\begin{array}{c}53.6 \\
(27.5-79.4)\end{array}$ & $\begin{array}{c}2.43 \\
(1.50-3.73)\end{array}$ & $\begin{array}{c}0.38 \\
(0.14-0.62)\end{array}$ & $\begin{array}{c}0.28 \\
(0.12-0.44)\end{array}$ & $\begin{array}{c}0.26 \\
(0.14-0.38)\end{array}$ \\
\hline Day 5 & $\begin{array}{c}12.5 \\
(10.0-15.3)\end{array}$ & $\begin{array}{c}50.5 \\
(29.6-74.1)\end{array}$ & $\begin{array}{c}2.80 \\
(1.60-4.18)\end{array}$ & $\begin{array}{c}0.56 \\
(0.30-0.82)\end{array}$ & $\begin{array}{c}0.31 \\
(0.11-0.51)\end{array}$ & $\begin{array}{c}0.37 \\
(0.13-0.61)\end{array}$ \\
\hline Day 30 & $\begin{array}{c}11.8 \\
(10.0-13.6)\end{array}$ & $\begin{array}{c}44.7 \\
(26.9-62.5)\end{array}$ & $\begin{array}{c}2.54 \\
(1.50-4.14)\end{array}$ & $\begin{array}{c}0.59 \\
(0.37-0.81)\end{array}$ & $\begin{array}{c}0.37 \\
(0.15-0.59)\end{array}$ & $\begin{array}{c}0.56 \\
(0.22-0.90)\end{array}$ \\
\hline Day 90 & $\begin{array}{c}12.3 \\
(10.0-14.6)\end{array}$ & $\begin{array}{c}39.5 \\
(28.3-50.7)\end{array}$ & $\begin{array}{c}2.46 \\
(1.50-3.52)\end{array}$ & $\begin{array}{c}0.83 \\
(0.45-1.21)\end{array}$ & $\begin{array}{c}0.45 \\
(0.23-0.67)\end{array}$ & $\begin{array}{c}0.76 \\
(0.40-1.12)\end{array}$ \\
\hline Day 180 & $\begin{array}{c}12.5 \\
(10.0-15.0)\end{array}$ & $\begin{array}{c}37.5 \\
(21.7-53.3)\end{array}$ & $\begin{array}{c}2.28 \\
(1.50-3.60)\end{array}$ & $\begin{array}{c}0.90 \\
(0.52-1.28)\end{array}$ & $\begin{array}{c}0.57 \\
(0.31-0.83)\end{array}$ & $\begin{array}{c}0.82 \\
(0.44-1.20)\end{array}$ \\
\hline
\end{tabular}

All values are given as a mean followed by lower and upper limit (95\% of confidence interval). From Andrew $\mathrm{M}$ at al., modified.[3]

\footnotetext{
* Correspondence: mario.motta@spedalicivili.brescia.it

Neonatology and Neonatal Intensive Care Unit, Children's Hospital of Brescia,
}

Italy 


\section{Reference ranges of coagulation tests in moderate and late preterm infants}

Considering the developmental changes of coagulation proteins in term and preterm neonates, specific agerelated reference ranges are necessary for an accurate diagnosis and management of neonatal coagulation disorders. In table 1 reference ranges for coagulation assays obtained in moderate and late preterm neonates are summarized.[3] Since coagulation assays are analyzer and reagent dependent, laboratories should develop specific reference ranges to their own testing systems.[4]

\section{New diagnostic assays}

Thromboelastography and the measurement of thrombin generation are methods that provide a global assessment of hemostasis. Recently, the use of these assays has been reported in neonates and the results suggest that these methods may offer advantages for the evaluation of developmental hemostasis. Thromboelastography, in particular, may be less sensitive to age-related changes of coagulation protein.[5,6] However, the introduction of these methods into clinical practice of neonatal medicine should be based on larger studies confirming the predictive value of the assays.

Published: 9 October 2014

\section{References}

1. Andrew M: The relevance of developmental hemostasis to hemorrhagic disorders of newborns. Semin Perinatol 1997, 21:70-85.

2. Monagle $P$, Massicotte P: Developmental haemostasis: secondary haemostasis. Semin Fetal Neonatal Med 2011, 16:294-300.

3. Andrew M, Paes B, Milner R, Johnston M, Mitchell L, Tollefsen DM, Castle V, Powers P: Development of the human coagulation system in the healthy premature infant. Blood 1988, 72:1651-7.

4. Monagle $\mathrm{P}$, Ignjatovic $\mathrm{V}$, Savoia H: Hemostasis in neonates and children: pitfalls and dilemmas. Blood Rev 2010, 24:63-8.

5. Edwards RM, Naik-Mathuria BJ, Gay AN, Olutoye OO, Teruya J: Parameters of thromboelastography in healthy newborns. Am J Clin Pathol 2008, 130:99-102.

6. Tripodi A, Ramenghi LA, Chantarangkul V, De Carli A, Clerici M, Groppo M, Mosca F, Mannucci PM: Normal thrombin generation in neonates in spite of prolonged conventional coagulation tests. Haematologica 2008, 93:1256-9.

doi:10.1186/1824-7288-40-S2-A38

Cite this article as: Motta and Russo: Developmental haemostasis in moderate and late preterm infants. Italian Journal of Pediatrics 201440 (Suppl 2):A38.
Submit your next manuscript to BioMed Central and take full advantage of:

- Convenient online submission

- Thorough peer review

- No space constraints or color figure charges

- Immediate publication on acceptance

- Inclusion in PubMed, CAS, Scopus and Google Scholar

- Research which is freely available for redistribution

Submit your manuscript at www.biomedcentral.com/submit 